\title{
A New Look at the Democracy-Environment Nexus: Evidence from Panel Data for High- and Low-Income Countries
}

\author{
Soohyeon Kim ${ }^{1, * \mathbb{D}}$, Jungho Baek ${ }^{2} \mathbb{D}$ and Eunnyeong Heo ${ }^{1}$ \\ 1 Department of Energy Systems Engineering, College of Engineering, Seoul National University, \\ Seoul 08826, Korea; heoe@snu.ac.kr \\ 2 Department of Economics, School of Management, University of Alaska Fairbanks, \\ Fairbanks, AK 99775, USA; jbaek3@alaska.edu \\ * Correspondence: kimssoo@snu.ac.kr
}

Received: 7 March 2019; Accepted: 16 April 2019; Published: 19 April 2019

\begin{abstract}
This study is to investigate whether the multifaceted roles of democracy have a positive relationship with environmental quality. Using a panel data of 132 high- and low-income countries from 2014 to 2016, a random effect (RE) model is analyzed in comparison with cross-sectional analysis. To pursue the current research thoroughly, five elements of democracy that encompass the aspects of democratic institutions (election system, civil liberties, and government function) and the aspects of democratic culture (political participation and political culture) are selected. We find that elements of democracy are positively correlated with the environment in high-income countries. In low-income countries, on the other hand, it is found that the role of democracy in explaining the environmental quality appears to be very weak; only the effect of government function positively relates with the environment.
\end{abstract}

Keywords: Democracy; environment; environmental Kuznets curve; panel data

\section{Introduction}

Traditionally, democracy offers effective procedural measures to solve environmental problems: a democratic institution mediates conflicts among various stakeholders such as environmentalists, consumers, and citizens, and a democratic government implements a consensus through environmental policies and regulations. As democracy develops, therefore, the quality of decision-making on environmental issues tends to improve. There are historical evidences from democratic countries indicating that democratic mechanisms resolve intense conflicts of interests concerning environmental problems [1-3].

Recently, however, the role of the existing democracy in solving environmental problems has been questioned. Klein [4] discusses in her journalistic book the limitations of traditional democracy and argues that the democracy may no longer be capable of managing climate change and environmental destruction. She provides several examples in which despite democratic efforts like referendum and official discussion to resist the indiscriminate development of resources, they have only resulted in severe conflicts between developers and local residents, with the problems being deteriorating in many parts of the world. Thus, for the environmental issues to be effectively solved, she insists that active and radical participation by the public and individuals be required.

Nowadays, environmental issues indeed need participatory democracy. Citizens as individuals attempts to find a survival strategy against environmental threats by mobilizing various methods of promoting citizen participation. For example, a small community, such as a transition town ('Transition town' refers to a local community project aimed at enhancing self-sufficiency to reduce 
the environmental impact of climate change), encourages citizens to attend the city hall meetings and share various ideas such as enhancing food safety by activating local agriculture or building energy-efficient houses that are favorable to the environment. Also, when intense conflicts emerge regarding fossil fuel development, climate change, and environmental pollution, citizens arrange a public inquiry and create a forum for open and pluralistic discussion, wherein a development project is examined directly by residents, environmental organizations, and consumers. They also utilize citizen jury, consensus meeting, and deliberative opinion polls to discuss environmental agendas in an unbiased and democratic manner. Radical changes and active participation in the personal dimension have contributed to supplementing and improving liberal democratic institutions in relation to environmental problems. In Germany, for example, individual citizens and local civic associations have pressured the government into expanding investments in renewable energy [1]. In France, there is an example that people have successfully protested against unconventional fuel development companies, compelling the government to issue a ban on fracking [4].

In resolving environmental problems, we can ask if democracy is still effective in improving the environment, seeing that the traditional role of democracy is facing limitations and more diverse democratic methods are required. Therefore, this study attempts to answer the question and identify whether broadened roles of democracy correlate to environmental improvement by using a panel data set of 132 countries from 2014 to 2016. Five democracy indices are incorporated to reflect the expanded concept and elements of current democracy: (1) election system, (2) civil liberties, (3) government function, (4) political participation, and (5) political culture. Election system, civil liberties, and government function represent the aspects of democratic institutions, while political participation and political culture characterize the aspects of democratic culture. Since income plays a strong role in determining environmental outcomes, for a careful analysis we split the full sample of 132 countries into high- and low-income countries based on the World Bank classification. In doing so, we can measure the effect of democracy on the environment in different income groups separately.

The paper is structured as follows. First, we review theoretical and empirical studies on the relationship between democracy and the environment. Then, we discuss our empirical framework, data, and present our results. Some concluding remarks follow.

\section{Literature Review on the Relationship between Democracy and the Environment}

\subsection{A Review of the Theoretical Literature}

Whether democracy is good or bad for the environment has been debated intensively over many decades. The theoretical literature on the topic can be reduced into two groups. The first group focuses on the aspects of democratic institutions and attempts to provide an answer to the question of whether democracy as a political system can achieve environmental protection effectively [5-11]. For example, Hardin [5] and Ophuls [6] argue that since selfish individuals of liberal democracies are likely to exploit nature for private profits, liberal democratic institutions have the immanent characteristic of destroying the environment. Goodin [7] also adds that democracy can be an inefficient political and procedural means to solve environmental problems. Saward [8] further points out that since the environmental crisis demands a quick and bold decision from the government, a dictatorship is more efficient, or that since scientific and technological expertise are needed to overcome environmental threats, a technocratic government is superior. On the other hand, Barry [9] defends the importance of democratic procedures in solving environmental problems, arguing that true environmental protection can be achieved by reflecting various opinions of stakeholders along with those of the political elite or specialists. Payne [12] states that the democratic procedure, which guarantees individual rights, political participation, regime responsiveness, information shares, and international coordination, encourages the government to reflect the public environmental needs. Unlike democracies that consider the environment as a public good, Winslow [10] and Ward [11] state that autocracies see it as a target of exploitation. Congleton [13] claims that since autocracy generally tends to eliminate political instability, 
it prefers a short-term and visible policy (i.e., economic growth) and nearly prevents long-term policy and environmental protection regulations. In autocratic nations, war and civil war are also factors devastating environment, according to Russett and Oneal [14].

The second group turns its attention to recognize the role of civil society in democratization processes in finding a fundamental solution to environmental problems [15-22]. For example, Dobson [16] and Dobson and Bell [20] argue that neither the ecofriendly improvement of democracy nor the governmental enforcement of environmental regulations is sufficient; instead, these measures should be accompanied by changes in personal 'belief, attitudes, and behavior' 'at a deep level', which is referred to as ecological citizenship. (Ecological citizenship can be defined from three different perspectives: republicanism, transnationalism, and liberal democracy. The Republican and transnational perspectives emphasize changes in the personal dimension. Therefore, the cultivation of ecological citizenship and active participation of individuals is a more fundamental solution to environmental problems than the enforcement of state-imposed systems or regulations $[9,16,20]$. However, environmental citizenship, interpreted by the liberal democratic view, focuses on improving systems or regulations of liberal democracies. In liberal democracies without environmental citizenship, the environment is treated as a property, not as a basic necessity for human survival. The liberal democratic environmental citizenship, however, includes a procedural right to participate in democratic decision-making of environmental policy to ensure the provision of the basic human necessity (clean environment). In other words, the liberal democratic environmental citizenship covers environmental rights along with the existing social and political rights [19]. Therefore, it not only accepts the existing systems and regulations of liberal democracies but also demands the improvement of relevant laws and systems to guarantee environmental rights [23].) Barry [21] further states that in addition to a sense of responsibility and justice for the environment, ecological citizens 'have a duty to participate so that they might challenge environmentally destructive development and demand the kinds of changes that would bring about sustainability,' thereby specifying the sense of responsibility and participation as the duty of each person. Dobson [22] adds that through participatory democracy, ecological citizens become individuals who engage in 'proenvironmental practice, in public and in private, driven by a belief in the fairness of the distribution of environmental goods, in participation, and in the cocreating of sustainability policy'. Thus, participatory democracy has been being emphasized as an alternative to existing democracy which has limitations [18].

\subsection{A Review of the Empirical Literature}

The empirical literature on the democracy-environment nexus mostly uses two kinds of democracy indices, which put weights on traditional roles of democracy. The first is the Polity index provided by the Integrated Network for Societal Conflict Research (INSCR) as a measure of the democratic structure of the government [11,23-26]. Focusing on competitiveness and election systematization, Polity data use numerical scores to indicate whether a political authority and regime-type are closer to dictatorship or democracy. The second is the political rights and civil liberties indices of the Freedom House and they measure the level of democracy in a country [10,13,27-29]. Political rights in this index refer to the existence and fairness of elections, existence of opposition and the possibility to gain power via elections. Civil liberties refer to the freedom of assembly, right to open and free discussion, independence of media and prevalence of the rule of law [30]. Notably, these two indices primarily measure the legal and institutional aspects of democracy.

However, criticisms can be made of the current empirical literature on the democracy-environment nexus. First, many previous studies use past data that were at least a decade old and hence lack temporal validity. For example, a number of studies use datasets from the 1990s—Bhattarai and Hammig [27] for the 1972 to 1991 period, Frankel and Rose [25] for the year 1990, Van and Azomahou [28] for the 1972 to 1994 period, and Ward [11] for the 1995 to 2001 period. Thus, the analyzed period needs to be updated to identify the current relationship between democracy and the environment. Second, the emphasis of the existing empirical research is typically on the effect of the legal and institutional 
aspects of democracy since they use the Polity index and Freedom House index as democracy variable. According to EIU [31], such Polity index and Freedom House index, measure a narrower and minimal concept of democracy limited to electoral democracy with competing multiparties and a few aspects of freedoms and liberties. Therefore, they are considered to have limitations in not encompassing broadened and substantive aspects of democracy. When it comes to the environment, however, various elements of democracy can work on improving the environment as introduced in the literature review, so empirical studies also need to analyze such multifaceted aspects of democracy, including not only institutional systems but also democratic culture and public participation.

Therefore, this study attempts to examine the recent democracy-environment nexus with up-to-date data from 2014 to 2016 and investigate multifaceted aspects of democracy from democratic institutions to democratic culture. To do this, we use the democracy index created by the Economist Intelligence Unit. The EIU's democracy index is advantageous to Polity index and Freedom House index in not only measuring institutional and systematic requirements (electoral process and pluralism, civil liberties, and the functioning of government), but also encompassing social and cultural aspects (political participation and political culture) [32].

\section{An empirical framework}

We use the panel data for the recent three years—2014, 2015 and 2016-when both democracy and environmental quality index are available on 132 countries to determine the effect of democracy on the environment. The empirical model for the three years is

$$
E_{i t}=\beta_{0}+\delta_{1} d 15_{t}+\delta_{2} d 16_{t}+\beta_{1} D_{i j t}+\beta_{2} Y_{i t}+\beta_{3} Y_{i t}^{2}+a_{i}+u_{i t}
$$

where $E_{i t}$ is the environmental quality in period $t$ for country $i . d 15_{\mathrm{t}}$ and $d 16_{\mathrm{t}}$ denote dummy variables for 2015 and 2016, respectively, which control yearly differences in estimating the coefficients of democracy and income variables. $D_{i t}$ is the democracy index $j$ in period $t$ for country $i$; we are interested in the parameter $\beta_{1}$. The elements of democracy to be considered in this study include the aspects of democratic institutions such as election system $\left(D_{\text {elect }}\right)$, civil liberties $\left(D_{\text {libert }}\right)$, and government function $\left(D_{\text {gov }}\right)$, and the aspects of democratic culture such as political participation $\left(D_{\text {part }}\right)$ and political culture $\left(D_{\text {cult }}\right)$. The categorization is based on the arguments of the EIU [31], which created the democracy index as an alternative to Polity index and Freedom House index. For comparison, the weighted average of those five elements of democracy $\left(D_{\text {all }}\right)$ is also considered. Democracy is correlated with the environment when the coefficient on $D_{\mathrm{it}}$ is positive. $Y_{i t}$ is the gross national income (GNI) per capita. In order to test the environmental Kuznets curve (EKC) hypothesis, $Y_{i t}{ }^{2}$ is included and captures decreasing and increasing the marginal effect of income on the environment. The EKC states that income has a diminishing (increasing) effect on environmental quality after (before) a turning point. As a result, the EKC holds when the coefficient on $Y_{i t}$ is positive and the coefficient on $Y_{i t}{ }^{2}$ is negative. $a_{\mathrm{i}}$ is the unobserved country effect and represents fixed factors that affect the environment in country $i$. Finally, $u_{\text {it }}$ is the time-varying error.

When applying panel data methods, it is common to use both a random effects (RE) estimator and a fixed effects (FE) estimator, and then conduct the Hausman test to determine an appropriate estimator [33]. The results of the Hausman test show that the null hypothesis cannot be rejected, suggesting that the RE is preferred to the FE (Tables 2 and 3). The RE is applicable to independent variables that do not change significantly over time. Thus, in our environment equation, we can include a variable such as democracy even if it is almost constant over time for many countries. For these reasons, we use RE rather than FE when estimating Equation (1). (Rigorously speaking, RE applies to randomly selected samples and FE to samples which itself equals to the population (e.g., OECD members, fifty states in the US, etc.). When the samples are selected on their availability, it is difficult to strictly determine between the RE and FE, thus the model selections rather depends on a researcher's judgement. Thus, we adopted the RE method based our rationale considering the cases 
of Winslow [10] and Van and Azomahou [28], where the RE was applied to the data chosen on its availability not randomly drawn.) To alleviate the assumption that error terms of the sampled data are independent, a clustered sandwich estimation was employed, and autocorrelation in error terms is corrected. Thus, we use the feasible generalized least squares (FGLS) and calculate a standard error by relaxing the assumption that error terms are independent of each other within a panel group.

Additionally, we conducted a cross-sectional analysis with 2014, 2015, and 2016 averages to check the robustness of the model of Equation (1) and to compare the results with and without random effects. In this analysis, the income variable is differently controlled depending on the dataset: for the full-sample of 132 countries, both $Y$ and $Y^{2}$ are included on the assumption that the relation of environment and logged income is quadratic; for the high- and low-income countries, only $Y$ is included on the possibility that their correlation is linear. To calibrate the heterogeneity of the errors, the robust standard errors are estimated.

\section{Data}

The environmental quality index from Social Progress Imperative (SPI) constructed by Porter and Stern [34-36] is used as a proxy for the environmental variable. As the motive of the SPI index is to measure the level of life quality going beyond the limits of GDP, its environmental quality index does not focus on individual pollution levels but encompass overall environmental qualities to score how much people are given environmentally quality life. Greenhouse gas emissions, wastewater treatment, and biodiversity are included in this index. (For the air pollution, emissions of carbon dioxide, methane, nitrous oxide, hydrofluorocarbons, perfluorocarbons, and sulfur hexafluoride expressed in CO2 equivalents using 100 year global warming potentials found in the Intergovernmental Panel on Climate Change Second Assessment Report per GDP-PPP (source: World Resources Institute) is considered for the wastewater treatment, baseline water stress, or the ratio of total annual water withdrawals to total available annual renewable supply are scored (source: World Resources Institute), and for biodiversity, the protection of terrestrial and marine areas as well as threatened or endangered species, comprising Critical Habitat Protection, Terrestrial Protected Areas (National Biome Weight), Terrestrial Protected Areas (Global Biome Weight), and Marine Protected Areas are used (source: Yale Center for Environmental Law \& Policy and Columbia University Center for International Earth Science Information Network Environmental Performance Index) [34-36].) The five democracy indices measuring the five aspects of democratic criteria are collected from the Economist Intelligence Unit (EIU). (The EIU's democracy index and its five subindices are created from experts' assessments, public opinion surveys (the World Value Survey, Eurobarometer surveys, Gallup polls, Asian Barometer, Latin American Barometer, Afrobarometer, and national surveys) and voter turnouts. Based on these raw data, 60 detailed indicators are rated first with a combination of dichotomous and a three-point scoring system and then grouped into five subindices (electoral process and pluralism, civil liberties, the functioning of government, political participation, and political culture). The overall Index is the simple average of the five subindices [34-36].) The election system indicates dissemination, fairness, transparency, and institutional guarantees of central and local government elections. Civil liberties indicate the degree of the legal protection of freedom of speech, freedom of expression, freedom of assembly and association, freedom of religion, private property right, and popular perceptions on protection of human rights. Government function is related to administration and measures its decision-making power for policy, the ability to accomplish official duties, level of corruption, and independence from the army, foreign influence, and special interests. Political participation indicates voters' participation in the election, citizens' political participation, the scope of such participation, minorities' political right to speak, and the government's efforts to promote political participation. Political culture estimates public support for democracy in comparison with autocracy, involvement level of military regime and technocratic government, and democracy's distribution to the economic systems. Note that since all democracy indices are provided on a $0-10$ scale, the $0-100$ scale for the SPI index is also converted to $0-10$ for consistency. The per capita income is measured by the logarithm of 
Gross National Income (GNI) per capita in constant 2011 dollar and is taken from the Social Progress Index. The classification of high- and low-income countries follows World Bank. (The WB classifies countries into four groups according to the gross national income (GNI). As of 2015, less than $\$ 1025$ GNI is the low-income group; $\$ 1026-4034$ GNI is the lower-middle income group; $\$ 4036-12,475$ is the upper-middle income group; and more than $\$ 12,476 \mathrm{GNI}$ is the high-income group. However, if this classification is applied without modification, the observations are insufficient. Therefore, for this study, we combined the low and lower-middle income countries in the low-income group, and the upper-middle and high-income countries in the high-income group.) Table 1 presents the descriptive statistics of the variables.

Table 1. Descriptive statistics.

\begin{tabular}{|c|c|c|c|c|c|c|c|c|c|}
\hline & & $E$ & $D_{\text {all }}$ & $D_{\text {elect }}$ & $D_{\text {libert }}$ & $D_{\text {gov }}$ & $D_{\text {part }}$ & $D_{\text {cult }}$ & $Y$ \\
\hline \multirow{4}{*}{ All countries } & Mean & 5.69 & 5.86 & 6.93 & 6.50 & 5.30 & 5.35 & 5.70 & 15,476 \\
\hline & Std. Dev. & 1.54 & 2.08 & 2.95 & 2.61 & 2.28 & 1.79 & 1.66 & 14,805 \\
\hline & Max & 9.23 & 9.93 & 10 & 10 & 9.64 & 10 & 10 & 84,188 \\
\hline & Obs. & 396 & 396 & 374 & 396 & 390 & 396 & 396 & 391 \\
\hline \multirow{3}{*}{$\begin{array}{l}\text { High-income } \\
\text { countries }\end{array}$} & Min & 0.67 & 1.82 & 0.50 & 1.47 & 0.07 & 1.67 & 2.50 & 2,930 \\
\hline & Max & 9.23 & 9.93 & 10 & 10 & 9.64 & 10 & 10 & 84,188 \\
\hline & Obs. & 237 & 237 & 225 & 237 & 237 & 237 & 237 & 232 \\
\hline \multirow{2}{*}{$\begin{array}{l}\text { Low-income } \\
\text { countries }\end{array}$} & Mean & 5.11 & 4.66 & 5.35 & 5.07 & 3.99 & 4.37 & 5.02 & 3,669 \\
\hline & Std. Dev. & 1.30 & 1.60 & 2.75 & 2.16 & 1.81 & 1.52 & 1.06 & 2,684 \\
\hline
\end{tabular}

Note: $D_{\text {all }}, D_{\text {elect }}, D_{\text {gov }}, D_{\text {part }}, D_{\text {cult }}$, and $D_{\text {libert }}$ represent aggregate democracy index, election system index, government function index, political participation index, political culture index, and civil liberties index, respectively. $Y$ indicates Gross National Income (GNI) per capita in constant 2011 dollar.

\section{Empirical Results}

Tables 2 and 3 contain the estimation results from random effects (RE) estimators. From the results of the full sample of 132 countries in Table 2, the estimated coefficient of the aggregate democracy index $\left(D_{\text {all }}\right)$ on the environment is positive, meaning that improved democracy in a country is correlated with environmental quality. In addition, the estimated coefficients on the aspects of democratic institutions such as election system $\left(D_{\text {elect }}\right)$, civil liberties $\left(D_{\text {libert }}\right)$, and government function $\left(D_{\text {gov }}\right)$ are all positive, suggesting that more advanced democratic systems positively correlate to the environment. The same is true of the aspects of democratic culture such as political culture $\left(D_{\text {cult }}\right)$. Statistically, it is significant for all the cases except for political culture at the $1 \%$ level. In terms of per capita income, the estimated coefficients of income variables are negative and positive for linear and quadratic terms respectively, showing a convex shape of the income function. Statistically, the coefficients are significant for all six cases. This suggests that environmental quality decreases at low levels of income, but increases at high levels. Further, when calculating the turning points for each case, they are found to fall within the sample period, and they range from 7.237 (\$1389) to 8.279 (\$3940). Thus, the results are generally supportive of the environmental Kuznets curve.

In Table 3, we compare the democratic contributions to the environment between high- and low-income countries. For this purpose, following the World Bank's country classification, countries with per capita GNI of $\$ 4035$ or more are classified as high-income countries, and countries with per capita GNI less than $\$ 4035$ are classified as low-income countries. In the case of high-income countries, the estimated coefficient on the aggregate democracy index is positive, which means that every element of democracy positively correlates with the environment in high-income countries. Further, for the individual five elements of democracy, the estimates are all positive and statistically 
significant. Evidently, the aspects of democratic institutions and democratic culture both play a role in explaining the environment in high-income countries. In addition, the estimated coefficients on the income show a concave shape. However, the calculated turning points for each case are found to be above the upper limit of the income range in the sample, and hence the quadratic to the right of the value can be ignored. In high-income countries, therefore, the environment tends to increase monotonically with income growth.

In the case of low-income countries, on the other hand, the coefficients of democracy variables show indefinite signs and they are not statistically significant. The only case with a significant coefficient is the government function and its positive sign suggests that the democratic advancement of government function correlates with environmental improvement. Overall, there is little evidence supporting that democracy correlates with the environment in low-income countries. The estimated coefficients on the income terms are negative and positive, indicating a convex shape. Statistically, however, they are not significant for all cases, so there is no evidence supporting the EKC hypothesis in low-income countries.

The Hausman results in Tables 2 and 3 show that the estimates of RE models in our analysis are consistent, confirming the RE model is more efficient than the FE model. Therefore, incorporating RE can be statistically justified by the Hausman results, for our data and models.

A cross-sectional analysis was conducted for comparison, and the results are included in Tables 4 and 5. Since it was shown in the RE analysis that income has convex functions for full sample while monotonically increasing and insignificant for the high-and low-income countries, respectively, the inclusion of the income terms is set to vary depending on the dataset; the full sample has both $Y$ and $Y^{2}$ terms and subsamples have only $Y$ term. Overall results of the cross-sectional analysis are similar to those of the RE analysis, but several differences are found. For the full-sample countries, the results of democracy variables are identical to the RE results in that the coefficients of all these variables except for participation are significant. When democracy is political culture, however, the coefficients of income variables lost significance, which was significant at the $5 \%$ level in the RE results. The turning points are from 7.435 (\$1694) to 8.012 (\$3016), which are in a similar range of the RE results. In high-income countries, the results of the democracy variables are almost the same as in the RE analysis, and all the democracy variables are found significant at the $1 \%$ and $5 \%$ levels. When it comes to the income variable, it was confirmed that income and environmental quality has a linear relation, as expected from the RE results. When democracy is political culture, in particular, the coefficients of quadratic income variables were insignificant in RE analysis while that of the linear income variable is revealed to have a positive value at the $1 \%$ level. The low-income countries show that the governmental function correlates with the environmental quality at $1 \%$ significance level as in the RE analysis and the civil liberties also has a relation with the environment at the $10 \%$ level. With all democracy variables, the coefficients of income variables appear insignificant, which indicates that the relationship between income and environmental quality is not linear nor quadratic. 
Table 2. Estimated results of the full sample (random effect analysis).

\begin{tabular}{|c|c|c|c|c|c|c|}
\hline \multicolumn{7}{|l|}{ Dependent Variable: $E$} \\
\hline Independent Variables & $D_{\text {all }}$ & $D_{\text {elect }}$ & $D_{\text {libert }}$ & $D_{\text {gov }}$ & $D_{\text {part }}$ & $D_{\text {cult }}$ \\
\hline$D$ & $\begin{array}{c}0.260 * * * \\
(0.045)\end{array}$ & $\begin{array}{c}0.158^{* * *} \\
(0.034)\end{array}$ & $\begin{array}{c}0.202 * * * \\
(0.037)\end{array}$ & $\begin{array}{c}0.290 * * * \\
(0.040)\end{array}$ & $\begin{array}{c}0.074 \\
(0.057)\end{array}$ & $\begin{array}{c}0.153^{* * *} \\
(0.054)\end{array}$ \\
\hline$Y$ & $\begin{array}{c}-2.176^{* * *} \\
(0.774)\end{array}$ & $\begin{array}{c}-2.568^{* * *} \\
(0.892)\end{array}$ & $\begin{array}{c}-2.608^{* * *} \\
(0.807)\end{array}$ & $\begin{array}{c}-2.318^{* * *} \\
(0.783)\end{array}$ & $\begin{array}{c}-2.560 * * * \\
(0.983)\end{array}$ & $\begin{array}{c}-1.896^{* *} \\
(0.919)\end{array}$ \\
\hline$Y^{2}$ & $\begin{array}{c}0.137^{* * * *} \\
(0.043)\end{array}$ & $\begin{array}{c}0.164^{* * *} \\
(0.050)\end{array}$ & $\begin{array}{c}0.164^{* * *} \\
(0.045)\end{array}$ & $\begin{array}{c}0.140 * * * \\
(0.044)\end{array}$ & $\begin{array}{c}0.171^{* * *} \\
(0.056)\end{array}$ & $\begin{array}{l}0.131^{* *} \\
(0.053)\end{array}$ \\
\hline$d 15$ & $\begin{array}{l}-0.073 \\
(0.065) \\
\end{array}$ & $\begin{array}{l}-0.102 \\
(0.067) \\
\end{array}$ & $\begin{array}{l}-0.073 \\
(0.065) \\
\end{array}$ & $\begin{array}{l}-0.035 \\
(0.067) \\
\end{array}$ & $\begin{array}{c}-0.151^{* *} \\
(0.060)\end{array}$ & $\begin{array}{c}-0.129 * * \\
(0.063)\end{array}$ \\
\hline$d 16$ & $\begin{array}{c}1.063^{* * *} \\
(0.145)\end{array}$ & $\begin{array}{c}1.052 * * * \\
(0.153)\end{array}$ & $\begin{array}{c}1.075^{* * *} \\
(0.146)\end{array}$ & $\begin{array}{c}1.117^{* * * *} \\
(0.145)\end{array}$ & $\begin{array}{c}0.962 * * * \\
(0.141)\end{array}$ & $\begin{array}{c}0.995 * * * \\
(0.144)\end{array}$ \\
\hline Constant & $\begin{array}{c}12.069 * * * \\
(3.424)\end{array}$ & $\begin{array}{c}13.855^{* * *} \\
(3.939)\end{array}$ & $\begin{array}{c}13.987 * * * \\
(3.551)\end{array}$ & $\begin{array}{c}13.094 * * * \\
(3.468)\end{array}$ & $\begin{array}{c}13.929 * * * \\
(4.345)\end{array}$ & $\begin{array}{c}10.768^{* * * *} \\
(4.067)\end{array}$ \\
\hline $\begin{array}{c}R^{2}: \text { within } \\
\text { overall } \\
\text { between }\end{array}$ & $\begin{array}{l}0.3314 \\
0.3877 \\
0.4232 \\
\end{array}$ & $\begin{array}{l}0.3365 \\
0.3850 \\
0.4243 \\
\end{array}$ & $\begin{array}{l}0.3305 \\
0.3937 \\
0.4322 \\
\end{array}$ & $\begin{array}{l}0.3455 \\
0.4178 \\
0.4704 \\
\end{array}$ & $\begin{array}{l}0.3359 \\
0.3094 \\
0.3009 \\
\end{array}$ & $\begin{array}{c}0.3308 \\
0.328 \\
0.3326 \\
\end{array}$ \\
\hline $\begin{array}{c}\text { Hausman- } \chi^{2} \\
(p \text {-value })\end{array}$ & $\begin{array}{c}6.23 \\
(0.285)\end{array}$ & $\begin{array}{c}7.88 \\
(0.163)\end{array}$ & $\begin{array}{c}6.94 \\
(0.225)\end{array}$ & $\begin{array}{c}4.05 \\
(0.542)\end{array}$ & $\begin{array}{c}3.73 \\
(0.590)\end{array}$ & $\begin{array}{c}6.93 \\
(0.226)\end{array}$ \\
\hline Obs. & 391 & 369 & 391 & 385 & 391 & 391 \\
\hline Turning point & $\begin{array}{c}7.942 \\
(\$ 2813)\end{array}$ & $\begin{array}{c}7.829 \\
(\$ 2512)\end{array}$ & $\begin{array}{c}7.951 \\
(\$ 2838)\end{array}$ & $\begin{array}{c}8.279 \\
(\$ 3940)\end{array}$ & $\begin{array}{c}7.485 \\
(\$ 1781)\end{array}$ & $\begin{array}{c}7.237 \\
(\$ 1390)\end{array}$ \\
\hline
\end{tabular}

Note: Parentheses below coefficients are standard errors. ${ }^{* * *}, * *$, and ${ }^{*}$ refer to the statistical significance at the $1 \%, 5 \%$, and $10 \%$ levels, respectively. Logged and unlogged turning points are reported when coefficients of income variables are significant. 
Table 3. Estimated results of the subsamples (random effect analysis).

\begin{tabular}{|c|c|c|c|c|c|c|c|c|c|c|c|c|}
\hline \multirow{2}{*}{ Dependent Variable: $E$} & \multicolumn{6}{|c|}{ High-Income Countries } & \multicolumn{6}{|c|}{ Low-Income Countries } \\
\hline & & & & & & & & & & & & \\
\hline Independent Variables & $D_{\text {all }}$ & $D_{\text {elect }}$ & $D_{\text {libert }}$ & $D_{\text {gov }}$ & $D_{\text {part }}$ & $D_{\text {cult }}$ & $D_{\text {all }}$ & $D_{\text {elect }}$ & $D_{\text {libert }}$ & $D_{\text {gov }}$ & $D_{\text {part }}$ & $D_{\text {cult }}$ \\
\hline \multirow{2}{*}{$D$} & $0.323^{* * *}$ & $0.232 * * *$ & $0.251^{* * *}$ & $0.328^{* * *}$ & $0.141^{* *}$ & $0.241^{* * *}$ & 0.134 & 0.080 & 0.116 & $0.233^{* * *}$ & -0.039 & -0.035 \\
\hline & $(0.051)$ & $(0.040)$ & $(0.040)$ & $(0.049)$ & $(0.066)$ & $(0.057)$ & $(0.091)$ & $(0.054)$ & $(0.077)$ & $(0.075)$ & $(0.082)$ & $(0.108)$ \\
\hline \multirow[b]{2}{*}{$Y$} & $5.945^{* *}$ & 4.727 & $5.204^{*}$ & $6.235^{* *}$ & $6.171^{* *}$ & $6.749^{* *}$ & -1.238 & -0.756 & -1.187 & -2.349 & -1.522 & -1.448 \\
\hline & $(2.917)$ & (3.098) & $(2.797)$ & $(2.966)$ & $(2.836)$ & $(2.832)$ & $(2.436)$ & $(2.414)$ & $(2.410)$ & $(2.506)$ & $(2.624)$ & $(2.675)$ \\
\hline \multirow[b]{2}{*}{$Y^{2}$} & $-0.277^{*}$ & -0.208 & $-0.231^{*}$ & $-0.299 * *$ & $-0.274^{*}$ & $-0.317^{* *}$ & 0.086 & 0.057 & 0.083 & 0.144 & 0.111 & 0.105 \\
\hline & $(0.145)$ & $(0.155)$ & $(0.140)$ & $(0.148)$ & $(0.141)$ & $(0.140)$ & $(0.150)$ & $(0.149)$ & $(0.149)$ & $(0.155)$ & $(0.161)$ & $(0.165)$ \\
\hline \multirow[b]{2}{*}{$d 15$} & $-0.197^{* *}$ & $-0.225^{* * *}$ & $-0.225^{* * *}$ & $-0.151^{*}$ & $-0.309^{* * *}$ & $-0.208^{* *}$ & 0.025 & -0.013 & 0.033 & 0.113 & -0.013 & -0.007 \\
\hline & $(0.084)$ & $(0.081)$ & $(0.080)$ & $(0.083)$ & $(0.082)$ & $(0.087)$ & $(0.105)$ & $(0.106)$ & $(0.106)$ & $(0.115)$ & $(0.103)$ & $(0.103)$ \\
\hline \multirow{2}{*}{$d 16$} & $1.465^{* * *}$ & $1.427^{* * *}$ & $1.457^{* * *}$ & $1.507^{* * *}$ & $1.322 * * *$ & $1.449^{* * *}$ & 0.389 & 0.398 & 0.403 & $0.495^{*}$ & 0.341 & 0.346 \\
\hline & $(0.176)$ & $(0.187)$ & $(0.175)$ & $(0.172)$ & $(0.176)$ & $(0.182)$ & $(0.257)$ & $(0.271)$ & $(0.260)$ & $(0.267)$ & $(0.253)$ & $(0.251)$ \\
\hline \multirow[b]{2}{*}{ Constant } & $-28.050 *$ & -22.486 & $-24.944^{*}$ & $-28.646^{*}$ & $-29.255^{* *}$ & $-31.439^{* *}$ & 8.686 & 6.924 & 8.544 & 13.445 & 10.210 & 9.975 \\
\hline & (14.599) & (15.423) & (13.949) & $(14.800)$ & (14.194) & $(14.226)$ & (9.613) & (9.587) & $(9.529)$ & (9.958) & (10.431) & $(10.669)$ \\
\hline \multirow{3}{*}{$\begin{array}{c}R^{2}: \text { within } \\
\text { overall } \\
\text { between }\end{array}$} & 0.5881 & 0.5754 & 0.5870 & 0.5988 & 0.5774 & 0.5867 & 0.0619 & 0.0698 & 0.0625 & 0.0591 & 0.0698 & 0.0751 \\
\hline & 0.5261 & 0.5244 & 0.5330 & 0.5341 & 0.4254 & 0.4478 & 0.0617 & 0.0616 & 0.0707 & 0.1269 & 0.0325 & 0.0273 \\
\hline & 0.4915 & 0.4906 & 0.5018 & 0.5024 & 0.3395 & 0.3668 & 0.0617 & 0.0756 & 0.0763 & 0.1886 & 0.0111 & 0.0044 \\
\hline \multirow{2}{*}{$\begin{array}{l}\text { Hausman- } \chi^{2} \\
\text { (p-value) }\end{array}$} & 2.72 & 1.99 & 1.45 & 5.26 & 6.73 & 1.49 & 4.89 & 7.13 & 4.32 & 4.04 & 3.45 & 8.45 \\
\hline & $(0.743)$ & $(0.851)$ & $(0.919)$ & $(0.385)$ & $(0.241)$ & $(0.914)$ & $(0.180)$ & $(0.129)$ & $(0.229)$ & $(0.401)$ & $(0.327)$ & $(0.117)$ \\
\hline Obs. & 232 & 220 & 232 & 232 & 232 & 232 & 159 & 149 & 159 & 153 & 159 & 159 \\
\hline Turning point & $\begin{array}{c}10.731 \\
(\$ 45,752)\end{array}$ & & $\begin{array}{c}11.264 \\
(\$ 77,964)\end{array}$ & $\begin{array}{c}10.426 \\
(\$ 33,725)\end{array}$ & $\begin{array}{c}11.261 \\
(\$ 77,730)\end{array}$ & $\begin{array}{c}10.645 \\
(\$ 41,982)\end{array}$ & & & & & & \\
\hline
\end{tabular}

Note: Parentheses below coefficients are standard errors. ${ }^{* * *}, * *$, and ${ }^{*}$ refer to the statistical significance at the $1 \%, 5 \%$, and $10 \%$ levels, respectively. Logged and unlogged turning point are reported when coefficients of income variables are significant. 
Table 4. Estimated results of the full sample (cross-sectional analysis).

\begin{tabular}{|c|c|c|c|c|c|c|}
\hline \multicolumn{7}{|l|}{ Dependent Variable: $E$} \\
\hline Independent variables & $D_{\text {all }}$ & $D_{\text {elect }}$ & $D_{\text {libert }}$ & $D_{\text {gov }}$ & $D_{\text {part }}$ & $D_{\text {cult }}$ \\
\hline$D$ & $\begin{array}{c}0.277^{* * *} \\
(0.047)\end{array}$ & $\begin{array}{c}0.153^{* * *} \\
(0.037)\end{array}$ & $\begin{array}{c}0.215^{* * *} \\
(0.037)\end{array}$ & $\begin{array}{c}0.301^{* * *} \\
(0.044)\end{array}$ & $\begin{array}{c}0.095 \\
(0.061)\end{array}$ & $\begin{array}{c}0.207^{* * *} \\
(0.059)\end{array}$ \\
\hline Y & $\begin{array}{c}-1.914^{* *} \\
(0.884)\end{array}$ & $\begin{array}{c}-2.318^{* *} \\
(0.977)\end{array}$ & $\begin{array}{c}-2.453^{* * *} \\
(0.893)\end{array}$ & $\begin{array}{c}-2.274^{* * *} \\
(0.82)\end{array}$ & $\begin{array}{c}-2.305^{* *} \\
(1.047)\end{array}$ & $\begin{array}{l}-1.111 \\
(0.985)\end{array}$ \\
\hline$Y^{2}$ & $\begin{array}{c}0.121^{* *} \\
(0.05)\end{array}$ & $\begin{array}{c}0.149 * * * \\
(0.056)\end{array}$ & $\begin{array}{c}0.153^{* * *} \\
(0.05)\end{array}$ & $\begin{array}{c}0.135^{* * *} \\
(0.046)\end{array}$ & $\begin{array}{c}0.155^{* *} \\
(0.060)\end{array}$ & $\begin{array}{c}0.084 \\
(0.057)\end{array}$ \\
\hline Constant & $\begin{array}{c}11.316^{* * *} \\
(3.847)\end{array}$ & $\begin{array}{c}13.245^{* * *} \\
(4.241)\end{array}$ & $\begin{array}{c}13.705^{* * *} \\
(3.869)\end{array}$ & $\begin{array}{c}13.414^{* * *} \\
(3.551)\end{array}$ & $\begin{array}{c}13.132^{* * *} \\
(4.562)\end{array}$ & $\begin{array}{l}7.575^{*} \\
(4.286)\end{array}$ \\
\hline$R^{2}$ & 0.4196 & 0.3864 & 0.4303 & 0.4595 & 0.2892 & 0.3259 \\
\hline Obs. & 132 & 132 & 132 & 132 & 132 & 132 \\
\hline Turning point & $\begin{array}{c}7.901 \\
(\$ 2700)\end{array}$ & $\begin{array}{c}7.779 \\
(\$ 2390)\end{array}$ & $\begin{array}{c}8.012 \\
(\$ 3017)\end{array}$ & $\begin{array}{c}8.423 \\
(\$ 4551)\end{array}$ & $\begin{array}{c}7.435 \\
(\$ 1694)\end{array}$ & \\
\hline
\end{tabular}

Note: Parentheses below coefficients are standard errors. ${ }^{* * *}, * *$, and * refer to the statistical significance at the $1 \%, 5 \%$, and $10 \%$ levels, respectively. Logged and unlogged turning points are reported when coefficients of income variables are significant. 
Table 5. Estimated results of the subsamples (cross-sectional analysis).

\begin{tabular}{|c|c|c|c|c|c|c|c|c|c|c|c|c|}
\hline \multirow[b]{2}{*}{ Dependent Variable: $E$} & \multicolumn{6}{|c|}{ High-Income Countries } & \multicolumn{6}{|c|}{ Low-Income Countries } \\
\hline & & & & & & & & & & & & \\
\hline Independent Variables & $D_{\text {all }}$ & $D_{\text {elect }}$ & $D_{\text {libert }}$ & $D_{\text {gov }}$ & $D_{\text {part }}$ & $D_{\text {cult }}$ & $D_{\text {all }}$ & $D_{\text {elect }}$ & $D_{\text {libert }}$ & $D_{\text {gov }}$ & $D_{\text {part }}$ & $D_{\text {cult }}$ \\
\hline $\mathrm{D}$ & $\begin{array}{c}0.324^{* * *} \\
(0.052)\end{array}$ & $\begin{array}{c}0.234^{* * *} \\
(0.042)\end{array}$ & $\begin{array}{c}0.256^{* * *} \\
(0.041)\end{array}$ & $\begin{array}{c}0.318^{* * *} \\
(0.053)\end{array}$ & $\begin{array}{l}0.186^{* *} \\
(0.073)\end{array}$ & $\begin{array}{c}0.233^{* * *} \\
(0.069)\end{array}$ & $\begin{array}{l}0.167 \\
(0.1)\end{array}$ & $\begin{array}{c}0.058 \\
(0.059)\end{array}$ & $\begin{array}{l}0.135^{*} \\
(0.079)\end{array}$ & $\begin{array}{c}0.261^{* * *} \\
(0.082)\end{array}$ & $\begin{array}{l}-0.050 \\
(0.094)\end{array}$ & $\begin{array}{c}0.075 \\
(0.106)\end{array}$ \\
\hline Y & $\begin{array}{c}0.492 * * * \\
(0.168)\end{array}$ & $\begin{array}{c}0.652 * * * \\
(0.169)\end{array}$ & $\begin{array}{c}0.653 * * * \\
(0.149)\end{array}$ & $\begin{array}{c}0.353^{* *} \\
(0.175)\end{array}$ & $\begin{array}{c}0.765^{* * * *} \\
(0.211)\end{array}$ & $\begin{array}{c}0.545^{* * *} \\
(0.199)\end{array}$ & $\begin{array}{c}0.007 \\
(0.174)\end{array}$ & $\begin{array}{c}0.070 \\
(0.156)\end{array}$ & $\begin{array}{c}0.005 \\
(0.171)\end{array}$ & $\begin{array}{l}-0.211 \\
(0.198)\end{array}$ & $\begin{array}{c}0.135 \\
(0.157)\end{array}$ & $\begin{array}{c}0.117 \\
(0.144)\end{array}$ \\
\hline Constant & $\begin{array}{l}-0.942 \\
(1.708)\end{array}$ & $\begin{array}{l}-2.180 \\
(1.729)\end{array}$ & $\begin{array}{l}-2.291 \\
(1.628)\end{array}$ & $\begin{array}{c}0.641 \\
(1.788)\end{array}$ & $\begin{array}{l}-2.596 \\
(1.936)\end{array}$ & $\begin{array}{l}-0.738 \\
(2.091)\end{array}$ & $\begin{array}{c}4.276^{* * *} \\
(1.473)\end{array}$ & $\begin{array}{c}4.300 * * * \\
(1.472)\end{array}$ & $\begin{array}{c}4.380^{* * *} \\
(1.463)\end{array}$ & $\begin{array}{c}5.772 * * * \\
(1.481)\end{array}$ & $\begin{array}{c}4.261^{* * *} \\
(1.52)\end{array}$ & $\begin{array}{c}3.803^{* *} \\
(1.694)\end{array}$ \\
\hline$R^{2}$ & 0.4688 & 0.4792 & 0.4884 & 0.4748 & 0.2957 & 0.3198 & 0.0700 & 0.0331 & 0.0842 & 0.1727 & 0.0122 & 0.0128 \\
\hline Obs. & 132 & 132 & 132 & 132 & 132 & 132 & 132 & 132 & 132 & 132 & 132 & 132 \\
\hline
\end{tabular}

Note: Parentheses below coefficients are standard errors. ${ }^{* * *}, * *$, and ${ }^{*}$ refer to the statistical significance at the $1 \%, 5 \%$, and $10 \%$ levels, respectively. 


\section{Concluding Remarks}

In this study, the relationship between the multifaceted roles of democracy and environmental quality is explored. Five indices of democracy are incorporated to embody the key features of democracy: election system, civil liberties, government function, political participation, and political culture. This broadens the traditional concept of democracy that has confined to institutional roles to encompass civic participation and democratic culture in resolving environmental problems. The analysis expands the previous studies of pre-2000s using Polity index and Freedom House index, which limit the role of democracy to institutional and systematic aspects. In the analysis, panel data for the recent three years (2014-2016) from 132 countries are utilized and panel data analysis empirically quantifies the correlation between democracy and the environment.

As a result, it is shown that in high-income countries, the institutional and systematic factors of democracy (election system, civil liberties, and government function) have correlations with environmental quality. The results confirm the past democracy-environment relationship revealed based on Polity index $[10,24,25,37]$ and Freedom House index $[10,27,28]$ are valid until recently. Moreover, expanding on the previous studies, this study discovers that democratic advancement in public participation and democratic culture also has a significant relation with environmental quality in high-income countries. This finding suggests that people in high-income countries have various measures to democratically preserve the environment. In the case of low-income countries, on the other hand, we find that the role of democracy seems to be pretty weak in dealing with environmental problems; only the government function is found to promote the environment. This result is consistent with the findings of Torres and Boyce [38] that political institutions have a substantial effect and those of Van and Azomahou [28] that a political institution failure may worsen the environment in developing countries.

Even though in this kind of quantitative analysis it is inherently difficult to determine causality, the results provide policy implications about how to use democracy to improve the environmental quality of life. According to the results, in countries with a certain level of income, democratic actions by citizens, as well as the will of governments, significantly contribute to the improvement of the environment. The actions include active participation of citizens in environmental issues, a formation of debates, an exercise of power as decision makers, and the creation of a social atmosphere. Thus, if citizens have the will, they can seek ways to solve environmental problems using every element of democracy via individual rights, information shares, and regime responsiveness. In low-income countries, on the other hand, it is more important for the governments to establish and enforce environmentally friendly policies. While it is essential to provide an economically stable life for their citizens, the government should establish a balanced and long-term national policy between economic development and environmental protection so as not to deprive the people of their environmentally quality life. Furthermore, as environmental degradation and climate change are rapidly emerging as a global problem across national boundaries, international coordination systems between developed and developing countries should be further strengthened.

While this study contributes to the analysis of the role of democracy in the environment by using a new democracy indicator with a broader definition, there is room for analytic development. Our model includes minimal variables that fit the purpose of the analysis, but in some cases, variables such as population, land area, and trade can be omitted variables of this kind of model. Therefore, such additional control variables can be included for the purpose of research and for the accuracy of the analysis. Also, this study analyzed the short period of 2014 to 2016, in which both environmental and democracy data are available for 132 countries. However, as data accumulate over time and can be analyzed over more extended periods, panel analysis that takes into account the dynamics of the time series data can be performed.

Author Contributions: Conceptualization, S.K., J.B., and E.H.; methodology, S.K. and J.B.; formal analysis, S.K.; writing - original draft preparation, S.K. and. E.H.; writing - review and editing, J.B.; feedback and discussion, J.B. and E.H.; supervision and administration, J.B and E.H. 
Funding: This research received no external funding.

Conflicts of Interest: The authors declare no conflicts of interest.

\section{References}

1. Carter, N. The Politics of the Environment: Ideas, Activism, Policy; Cambridge University Press: New York, NY, USA, 2007.

2. Longhurst, J.L. Citizen Environmentalists (Civil Society: Historical and Contemporary Perspectives); Tufts University Press: Lebanon, NH, USA, 2010.

3. Van der Heijden, H.A. Handbook of Political Citizenship and Social Movements; Edward Elgar Publishing: Northampton, MA, USA, 2014.

4. Klein, N. This Changes Everything: Capitalism vs. the Climate; Simon and Schuster: New York, NY, USA, 2014.

5. Hardin, G. The tragedy of commons. Science 1968, 162, 1243-1248.

6. Ophuls, W. Ecology and the Politics of Scarcity; W.H. Freeman: San Francisco, CA, USA, 1977.

7. Goodin, R. Green Political Theory; Polity Press: Cambridge, UK, 1992.

8. Saward, M. Must democrats be environmentalists. In Democracy and Green Political Thought: Sustainability, Rights, and Citizenship; Doherty, B., de Geus, M., Eds.; Routledge: London, UK, 1996; pp. 79-96.

9. Barry, J. Rethinking Green Politics: Nature, Virtue and Progress; SAGE: London, UK, 1999.

10. Winslow, M. Is democracy good for the environment? J. Environ. Plan. Manag. 2005, 48, 771-783. [CrossRef]

11. Ward, H. Liberal democracy and sustainability. Environ. Politics 2008, 17, 386-409. [CrossRef]

12. Payne, R.A. Freedom and the environment. J. Democr. 1995, 6, 41-55. [CrossRef]

13. Congleton, R.D. Political institutions and pollution control. Rev. Econ. Stat. 1992, 74, 412-421. [CrossRef]

14. Russett, B.; Oneal, J.R. Triangulating Peace: Democracy Interdependence and International Organizations; W.W. Norton: New York, NY, USA, 2001.

15. Dryzek, J. Discursive Democracy: Politics, Policy, and Political SCIENCE; Cambridge University Press: New York, MY, USA, 1990.

16. Dobson, A. Citizenship and the Environment; Oxford University Press: Oxford, UK, 2003.

17. Smith, G. Deliberative Democracy and the Environment; Routledge: London, UK, 2003.

18. Eckersley, R. The Green State: Rethinking Democracy and Sovereignty; The MIT Press: Cambridge, MA, USA, 2004.

19. Bell, D. Liberal environmental citizenship. Environ. Politics 2005, 14, 179-194. [CrossRef]

20. Dobson, A.; Bell, D. Environmental Citizenship; The MIT Press: Cambridge, MA, USA, 2006.

21. Barry, J. Resistance is fertile. In Environmental Citizenship; Dobson, A., Bell, D., Eds.; MIT Press: Cambridge, MA, USA, 2006; pp. 21-48.

22. Dobson, A. Ecological citizenship revisited. In Handbook of Global Environmental Politics, 2nd ed.; Dauvergne, P., Ed.; Edward Elgar Publishing Ltd.: Cheltenham, UK; Northampton, MA, USA, 2012.

23. Hayward, T. Constitutional Environmental Rights; Oxford University: Oxford, UK, 2005.

24. Midlarsky, M.I. Democracy and the environment: An empirical assessment. J. Peace Res. 1998, 35, $341-361$. [CrossRef]

25. Frankel, J.A.; Rose, A.K. Is trade good or bad for the environment? Sorting out the causality. Rev. Econ. Stat. 2005, 87, 85-91. [CrossRef]

26. Povitkina, M. Democracy, Bureaucratic Capacity and Environmental Quality; QoG Working Paper Series; QoG Institute: Gothenburg, Sweden, 2015; p. 13.

27. Bhattarai, M.; Hammig, M. Institutions and the environmental Kuznets curve for deforestation: A cross-country analysis for Latin America, Africa, and Asia. World Dev. 2001, 29, 995-1010. [CrossRef]

28. Van, P.N.; Azomahou, T. Nonlinearities and heterogeneity in environmental quality: An empirical analysis of deforestation. J. Dev. Econ. 2007, 84, 291-309.

29. Mak Arvin, B.; Lew, B. Does democracy affect environmental quality in developing countries? Appl. Econ. 2011, 43, 1151-1160. [CrossRef]

30. Neumayer, E. Do democracies exhibit stronger international environmental commitment? A cross-country analysis. J. Peace Res. 2002, 39, 139-164. [CrossRef]

31. The Economist Intelligence Unit (EIU). Democracy Index 2016 Revenge of the "Deplorables"; The Economist: London, UK, 2016. 
32. Kim, Y.; Kim, S.; Baek, J.; Heo, E. The linkages between democracy and the environment: Evidence from developed and developing countries. Energy and Environment. 2018. [CrossRef]

33. Wooldridge, J.M. Introductory Econometrics: A Modern Approach, 5th ed.; Southern-Western College Pub.: Cincinnati, OH, USA, 2015.

34. Social Progress Imperative (SPI). Social Progress Index; SPI: Washington, DC, USA, 2014.

35. Social Progress Imperative (SPI). Social Progress Index; SPI: Washington, DC, USA, 2015.

36. Social Progress Imperative (SPI). Social Progress Index; SPI: Washington, DC, USA, 2016.

37. Farzin, Y.H.; Bond, C.A. Democracy and environmental quality. J. Dev. Econ. 2006, 81, 213-235. [CrossRef]

38. Torres, M.; Boyce, J.K. Income, inequality and pollution: A reassessment of the environmental Kuznets. Ecol. Econ. 1998, 25, 195-208. [CrossRef]

(C) 2019 by the authors. Licensee MDPI, Basel, Switzerland. This article is an open access article distributed under the terms and conditions of the Creative Commons Attribution (CC BY) license (http://creativecommons.org/licenses/by/4.0/). 